\title{
Koncentracija vlasništva i pokazatelji uspješnosti: dokazi sa Zagrebačke burze
}

Džanić, Alen

Source / Izvornik: Odabrani prijevodi, 2012, 3, 1 - 21

Journal article, Published version

Rad u časopisu, Objavljena verzija rada (izdavačev PDF)

https://doi.org/10.3326/op.11

Permanent link / Trajna poveznica: https:/urn.nsk.hr/urn:nbn:hr:242:784509

Rights / Prava: Attribution-NonCommercial-NoDerivatives 4.0 International/ImenovanjeNekomercijalno-Bez prerada 4.0 međunarodna

Download date / Datum preuzimanja: 2023-04-26

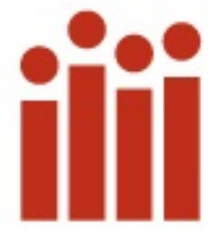

Repository / Repozitorij:

Institute of Public Finance Repository

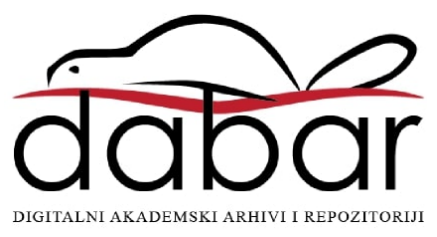




\section{KONCENTRAGIJA VLASNIŠTVA I POKAZATELJI USPJEŠNOSTI: DOKAZI SA ZAGREBAČKE BURZE}

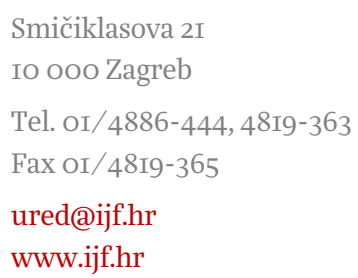

\section{ODABRANI PRIJEVODI}

\author{
ISSN I847-7445
}

\section{BR. II/I2}

\author{
ALEN DŽANIĆ, MA ${ }^{*} \quad$ Članak ${ }^{* *}$ \\ JEL: L22O \\ UDK: 336.78 \\ DOI: $10.3326 /$ op.11
}

\section{SAŽETAK}

Glavni je cilj rada utvrditi postojanje, te detaljnije istražiti odnose između vlasničke strukture i pokazatelja uspješnosti tortki izlistanih na Zagrebačkoj burzi u razdoblju izmеđu 2003. i 2009. Rezultati panel-analize s fiksnim efektima ukazuju na postojanje signifikantne negativne veze između postojanja velikog dioničara (preko 30\% vlasničkog udjela) i Tobinovog Q. U posebnom slučaju, kada uz prvog, postoji i drugi veliki dioničar koji je pojedinac/obitelj, efekt nestaje. Rad predstavlja $i$ potvrdu hipoteze o „mirnom životu“ postavljenu u radu Bertrand $i$ Mullainathana (2003) - s porastom vlasničkog udjela menadžmenta opada produktivnost rada. Pored toga, predstavljeni su i dokazi kako strano vlasništvo

\section{nije statistički signifikantno bolje od domaćeg.}

Ključne riječi: vlasnička struktura, koncentracija vlasništva, Tobinov Q, povrat na kapital, produktivnost rada, veliki dioničari, menadžersko vlasništvo, Zagrebačka burza

\footnotetext{
*Autor zahvaljuje trojici anonimnih recenzenata na korisnim komentarima i sugestijama.

"Primljeno: I. lipnja 2011.

Prihvaćeno: 6. studenog 2011.

Rad je nagrađen za najbolji studentski rad za godišnju nagradu Zaklade prof. dr. Marijan Hanžeković u $20 I I$.

Alen DŽANIĆ

Nador I7, IO5I Budimpešta, Madžarska

e-mail: alendzanic@hotmail.com
} 


\section{UvOD}

U posljednjih stotinjak godina otvoreno je nebrojeno mnogo pitanja o korporativnom upravljanju, ali na malo koje od njih je u potpunosti i nedvosmisleno odgovoreno. Različiti znanstvenici koristeći različite uzorke i metode često su dolazili do različitih, čak i međusobno suprotstavljenih zaključaka. Berle i Means (I932) bili su prvi koji su pokušali razjasniti utjecaj koncentracije vlasništva na uspješnost poslovanja tvrtki: kad menadžment posjeduje relativno mali udio u kapitalu, a vlasništvo dioničara je dovoljno raspršeno tako da ne postoji mogućnost prinude menadžmenta da se ponaša $\mathrm{u}$ cilju maksimizacije vrijednosti, postoji mogućnost korištenja imovine tvrtke na način koji pridonosi dobrobiti menadžmenta umjesto onih koji su u tu tvrtku uložili. Menadžer može, primjerice, iskoristiti slabosti malih dioničara kako bi radio na ostvarivanju osobnih interesa kao što su povećanje prodaje, izgradnja poslovnog carstva, povećanje plaća radnika kako bi se izbjegli potencijalni sukobi ili može jednostavno izbjegavati većinu svojih obveza bez straha od gubitka posla. S rastom vlasničkog udjela menadžera očekuje se nestanak ovog efekta jer interesi menadžmenta i ostalih vlasnika počinju konvergirati.

Zaključak Berlea i Meansa samo je jedno od potencijalnih teorijskih objašnjenja veze između strukture vlasništva i uspješnosti poduzeća koje naglašava važnost ovog problema. Proučavanje koncentracije vlasništva, njenih odrednica i posljedica još je važnije kad su u pitanju države u razvoju te gospodarstva u procesu tranzicije iz jednog ekonomskog sustava u drugi. U postkomunističkim zemljama srednje i istočne Europe, među ostalim i Hrvatskoj, vlasnička koncentracija još uvijek je najrašireniji mehanizam korporativnog upravljanja. Činjenica da su ove države relativno nedavno prošle kroz proces privatizacije čini ih još atraktivnijim za proučavanje utjecaja vlasničke strukture. Ovisno o načinu provođenja privatizacije, problem endogenosti je u najmanju ruku značajno reduciran. Konačno, analiza ovog problema omogućuje pristup informacijama koje nas mogu približiti definiciji optimalne vlasničke strukture i optimalnog vlasnika.

Iz prethodno navedenih razloga, dostupan je veliki broj radova koji se bave temom vlasništva u srednjoj i istočnoj Europi, ali po informacijama dostupnim autoru, ni jedan od njih nije ulazio u dublju analizu situacije u Hrvatskoj. Cilj je ovog rada identificirati posljedice menadžerskog vlasništva te postojanja velikih dioničara na poslovanje tvrtki izlistanih na Zagrebačkoj burzi. Slučaj Hrvatske zanimljiv je i zbog specifičnih okolnosti kojima je zemlja bila izložena u kasnim osamdesetim i prvoj polovici devedesetih godina prošlog stoljeća.

Naime, ekonomiju današnje Hrvatske u osamdesetim godinama karakteriziralo je radničko samoupravljanje, ekonomska liberalizacija i pojava malih, privatnih poduzeća. Prema tome, bilo bi za očekivati da će proces tranzicije iz socijalizma u kapitalizam proći bezbolnije nego u ostalim, u pravilu puno zatvorenijim, istočnoeuropskim državama. Međutim, proces rane tranzicije u Hrvatskoj tekao je paralelno s ratnim zbivanjima. U takvoj situaciji za očekivati je da je proces privatizacije bio manje transparentan i više navođen politikom, nego što bi to bilo u mirnodopskim vremenima. Također, rat na velikom dijelu teritorija Hrvatske odgodio je značajniji ulazak stranog kapitala sve do druge polovice 
devedesetih. Stoga, pri interpretaciji rezultata ovog istraživanja potrebno je uzeti u obzir i povijesnopolitičke specifičnosti Hrvatske.

Rezultati ovog istraživanja ukazuju na negativnu vezu između postojanja velikog dioničara i vrijednosti Tobinovog Q, što se pripisuje ostvarivanju dodatnih osobnih interesa od strane velikog vlasnika, a nauštrb malih dioničara. Ukoliko u tvrtki postoji i drugi veliki vlasnik, te je taj vlasnik pojedinac/obitelj, ostvarivanje dodatnih osobnih interesa prvog velikog vlasnika je otežano. Produktivnost rada je u pozitivnoj korelaciji s udjelom menadžmenta u vlasničkoj strukturi, te je veza između dvije varijable marginalno statistički signifikantna. Također, nisu pronađeni dokazi da je strano vlasništvo bolje od domaćeg, kao što je to slučaj u većini ostalih srednje razvijenih i zemalja u razvoju.

Rad ima sljedeću strukturu. Prvo poglavlje predstavlja uvod u temu istraživanja. Drugo poglavlje donosi sažetak relevantne literature. Više informacija o uzorku i podacima korištenim u empirijskom dijelu rada nalazi se u trećem poglavlju. U četvrtom poglavlju objašnjena je metodologija i rezultati analize. Peto poglavlje bavi se potencijalnim problemom endogenosti te posljednje, šesto poglavlje predstavlja kratak sažetak rezultata i zaključak istraživanja.

\section{Pregled literature}

Pregled literature pruža čitatelju više podrobnosti o samoj temi, te ukratko objašnjava dosadašnje rezultate istraživanja na ovom području, s kojima se rezultati ovog rada mogu usporediti. Veza između vlasničke strukture i uspješnosti poduzeća, kao što je već spomenuto, po prvi put je ozbiljnije obrađena u radu Berlea i Meansa (1932). Autori su ustvrdili kako je disperzija vlasništva direktno povezana s pogoršanjem uspješnosti poduzeća. Kad su menadžer i vlasnik dvije različite osobe, njihovi interesi se ne moraju nužno preklapati i dolazi do konflikta. Kad je vlasništvo disperzirano, menadžer izlazi iz konfliktne situacije kao pobjednik. Mali dioničari se obično ne mogu dovoljno efikasno organizirati te stoga nemaju gotovo nikakav utjecaj na menadžment. Troškovi nadzora su preveliki, te se mali dioničari obično niti ne pokušavaju upustiti u pokušaj nadgledanja rada menadžmenta. Nadzorni odbori čine se logičnim rješenjem ovog problema, ali isti su uglavnom nedovoljno efikasni. To je dijelom posljedica činjenice da članovi odbora imaju teži i ograničeniji pristup informacijama od menadžmenta. Nadalje, visoka i fiksna primanja članova nadzornih odbora ne potiču njihove članove da se aktivnije uključe u poslovanje tvrtke ili da ulaze u sukobe s menadžmentom.

Gotovo pola stoljeća nakon rada Berlea i Meansa, Demsetz (1983) pruža drugačiji pogled na problem vlasničke koncentracije. Demsetz tvrdi kako je vlasnička struktura pod direktnim utjecajem samih dioničara i prema tomu bi trebala biti tretirana kao endogena varijabla. Nadalje, Demsetz dolazi do zaključka da uspješnost poduzeća, u ovom konkretnom slučaju mjerena profitnom stopom, i vlasnička koncentracija nisu uzajamno povezani. U radu Demsetza i Lehna (1985) analizirano je petsto korporacija iz SAD-a. Dvije varijable su korištene kao mjera koncentracije vlasništva: količina dionica koju posjeduje pet najvećih dioničara te udio menadžmenta u vlasničkoj strukturi poduzeća. Rezultati modela su pokazali kako niti jedna od ovih vlasničkih varijabli nije povezana s profitnim stopama poduzeća. 
Himmelberg, Hubbard i Palia (1999) pružili su dodatne dokaze o endogenosti menadžerskog vlasništva. U svome modelu kontrolirali su kvantitativno mjerljive karakteristike poduzeća i fiksirali pojedinačne efekte te došli do rezultata kako je menadžersko vlasništvo uistinu nepovezano s indikatorima uspješnosti poslovanja promatranih poduzeća. Gugler i Weigand (2003) se nadovezuju na ovaj rad te koristeći veliki uzorak tvrtki iz SAD-a potvrđuju endogenost menadžerskog vlasništva, ali istovremeno pružaju dokaze da veliki vanjski dioničari utječu na uspješnost poslovanja egzogeno. Robusnost rezultata provjerili su primjenom istog modela na uzorku njemačkih poduzeća, što je rezultiralo vrlo sličnim zaključcima.

U posljednja dva desetljeća proveden je veliki broj istraživanja koja su često završila s međusobno suprotstavljenim rezultatima. Morck, Shleifer i Vishny (1988) su kao mjeru uspješnosti koristili Tobinov Q i došli do dokaza o postojanju statistički signifikantne nemonotone veze između koncentriranosti vlasništva i ovog pokazatelja uspješnosti. McConnel i Servaes (I990) koristeći paralelno Tobinov Q i povrat na imovinu kao mjere uspješnosti pronalaze korelaciju obje varijable s vlasničkom koncentracijom. Cho (1998) tvrdi kako vlasnička struktura utječe na količinu investicija u koje se poduzeće upušta, a potom nove investicije ponovno utječu na promjene u vlasničkoj strukturi što opet ukazuje na problem endogenosti. Uvodeći u model kontrolu za ovaj tip endogenosti, Cho dolazi do zaključka kako Tobinov Q raste s višom koncentracijom vlasništva do određene točke, a potom počinje opadati. Koristeći uzorak najvećih europskih tvrtki, Thomsen i Pedersen (200o) identificiraju pozitivan efekt koncentriranog vlasništva na pokazatelje uspješnosti poslovanja.

Postoji svega nekoliko značajnijih radova koji koriste alternativne pristupe kako bi odgonetnuli utjecaj vlasničke strukture na performanse poduzeća. Farinos (2006) koristi konkretne slučajeve u objašnjavanju povezanosti ove dvije varijable na primjeru Španjolske, dok Wyatt (1990) koristi sličan pristup u objašnjavanju utjecaja nadzornih odbora na performanse američkih tvrtki.

Kad je riječ o utjecaju porijekla vlasnika na poslovne performanse, rezultati istraživanja su međusobno puno sličniji, a autori usuglašeniji. Willmore (1986) pruža dokaze o superiornosti financijskih pokazatelja tvrtki u stranom vlasništvu u odnosu na domaće tvrtke, na primjeru Brazila. Chibber i Mujumdar (1999) dolaze do jednakog zaključka analizirajući situaciju u Indiji.

Međutim, ispostavlja se da je ovaj efekt strogo ograničen na zemlje u razvoju. Globerman (1994) ne pronalazi nikakve razlike u uspješnosti između kanadskih tvrtki koje imaju domaćeg ili stranog većinskog vlasnika. Kim i Lyn (I990) koristeći uzorak tvrtki iz SAD-a dolaze do rezultata da su tvrtke u čijem vlasništvu dominira strani kapital zapravo manje uspješne od domaćih. U Ujedinjenom Kraljevstvu Driffield i Girma (2003) ne pronalaze sistematske razlike u uspješnosti domaćih i stranih tvrtki, a do jednakog rezultata dolaze i Barbosa i Louri istražujući utjecaj porijekla vlasnika na performanse tvrtki u Grčkoj i Portugalu. 


\section{UZORAK I PODAGI}

Rad u analizi koristi službene podatke tvrtki izlistanih na Zagrebačkoj burzi u razdoblju od 2003. do 2009. U trenutku kad je analiza napravljena (svibanj, 20II), na Zagrebačkoj burzi ukupno je bilo izlistano 237 dioničkih društava. Od ukupnog broja, njih 58 je izlistano na burzi nakon prosinca 2003, te su stoga isključeni iz analize. Također, iz uzorka su isključene financijske i druge visoko regulirane tvrtke jer je njihova uspješnost često pod velikim utjecajem propisa nametnutih od strane Vlade, Hrvatske Narodne Banke ili drugih institucija. Za 24 tvrtke, veliki dio podataka nije objavljen te su također uklonjene iz uzorka. Nadalje, tvrtke s ekstremnim vrijednostima promatranih varijabli nisu uključene $\mathrm{u}$ regresijske jednadžbe. Nakon ovih isključenja, uzorak čini II9 tvrtki i 746 jedinica promatranja. ${ }^{\mathrm{I}}$

\section{I KONCENTRACIJA VLASNIŠTVA}

Svi podaci korišteni u ovom istraživanju prikupljeni su iz godišnjih financijskih izvještaja koje su tvrtke dužne dostaviti Zagrebačkoj burzi. U tablici I prikazani su osnovni statistički podaci o koncentriranosti vlasništva u Hrvatskoj u prvoj i posljednjoj godini promatranog razdoblja. Prikazani su podaci o prosječnom postotnom udjelu prvog, prva tri i prvih pet najvećih dioničara, te prosječni vlasnički udio menadžmenta.

TABLICA I.

Koncentracija vlasništva u hrvatskim tvrtkama (\% ukupnog broja izdanih dionica)

\begin{tabular}{lrrrrrrrr}
\hline & \multicolumn{1}{c}{ TOPI } & \multicolumn{1}{c}{ TOP3 } & \multicolumn{1}{c}{ TOP5 } & \multicolumn{2}{c}{ Menadžment } \\
\hline & $\mathbf{2 0 0 3 .}$ & $\mathbf{2 0 0 9 .}$ & $\mathbf{2 0 0 3 .}$ & $\mathbf{2 0 0 9 .}$ & $\mathbf{2 0 0 3 .}$ & $\mathbf{2 0 0 9 .}$ & $\mathbf{2 0 0 3 .}$ & $\mathbf{2 0 0 9 .}$ \\
\hline $\begin{array}{l}\text { Aritmetička } \\
\text { sredina }\end{array}$ & 52,74 & 52,43 & 54,03 & 55,89 & 75,91 & 75,42 & 3,97 & 3,98 \\
\hline Medijan & $54, \mathrm{I} 3$ & $54, \mathrm{I} 3$ & 56,04 & 59,31 & 85,91 & 85,59 & O & O \\
\hline Maksimum & 98,62 & 98,62 & IOO & IOO & IOO & IOO & IOO & IOO \\
\hline Minimum & 7,40 & 6,29 & I5,33 & I9,39 & I9,4O & 22,79 & O & O \\
\hline $\begin{array}{l}\text { Standardna } \\
\text { devijacija }\end{array}$ & 26,66 & 26,96 & 24,53 & 27,37 & 23,22 & 23,08 & \multirow{2}{*}{ I2,30 } & I2,99 \\
\hline
\end{tabular}

Iz tablice I vidljivo je kako se stanje s koncentracijom vlasništva u tvrtkama sa Zagrebačke burze nije značajnije promijenilo na kraju promatranog razdoblja u odnosu na početak. Vlasnički udio najvećeg dioničara varira između 6.29\% do čak 98.62\% oko prilično visokog prosjeka koji je nešto iznad 50\%. Ova činjenica ne treba previše iznenaditi čitatelja s obzirom na sličnu situaciju u drugim tranzicijskim i zemljama u razvoju, te kontinentalnoj Europi općenito. Medijan, koji je gotovo jednak aritmetičkoj sredini, govori kako u polovici svih promatranih tvrtki jedan dioničar ima apsolutnu moć u odlučivanju. Međutim, dionički udio ostalih velikih dioničara također nije zanemariv. U cilju istraživanja odnosa između velikih vanjskih vlasnika i pokazatelja uspješnosti poslovanja tvrtki, kreirana je binarna varijabla BI_30. Ova varijabla ima vrijednost I ukoliko najveći dioničar kontrolira preko 30\% kapitala tvrtke. Ukoliko najveći vlasnik kontrolira manje od 30\%, vrijednost varijable je nula.

${ }^{I}$ Očekivane su 833 jedinice promatranja, ali zbog nepotpunih izvještaja dostavljenih Zagrebačkoj burzi, pojedine tvrtke nisu uključene u uzorak u svim promatranim godinama. 
Sljedeća bitna informacija iz tablice I je da je medijan udjela menadžmenta u vlasništvu jednak nuli. Ovo je najvjerojatnije rezultat česte promjene menadžmenta te činjenica da se kompenzacije menadžerima u Hrvatskoj vrlo rijetko ostvaruju kroz isplatu u dionicama. U cilju istraživanja odnosa između menadžerskog vlasništva i uspješnosti tvrtki kreirana je varijabla Lmanager. Lmanager je logaritmička transformacija ${ }^{2}$ udjela menadžerskog vlasništva u ukupnom kapitalu. Kako bi otvorili mogućnost modelu da prepozna i eventualne nelinearne veze u odnosu između menadžerskog vlasništva i uspješnosti kreirana je i varijabla Lmanager^2 koja predstavlja kvadriranu vrijednost varijable Lmanager.

Menadžersko vlasništvo je predstavljeno kontinuiranom varijablom jer je za očekivati da menadžment čak i pri jako niskim razinama udjela u vlasničkom kapitalu ima utjecaja na uspješnost poslovanja tvrtke. S druge strane, vanjski dioničari do određene granice obično ne utječu na rad tvrtke. Tek kad postanu dovoljno veliki, vanjski vlasnici imaju mogućnost, a i motivaciju da pokušaju aktivno sudjelovati u radu tvrtke. Upravo to očekivanje je razlog zbog čega je vanjsko vlasništvo definirano kao binarna varijabla. Kao prijelomne točke promjene vrijednosti binarne varijable u modelu su isprobane vrijednosti od 20, 30 i 40\%. Rezultati su bili vrlo slični, s konstantnim predznacima koeficijenata ali s manjim varijacijama u njihovom intenzitetu. Autor se odlučio na korištenje 30\% kao prijelomne točke nakon uključivanja varijable B2_Io u regresijske jednadžbe. Takva kombinacija prijelomnih točaka dozvoljava dovoljan broj jedinica promatranja u kojima postoje i prvi i drugi veliki dioničar (vrijednost varijabli BI_30 i B2_ Io može istovremeno biti I). Veći uzorak svakako bi bio puno poželjniji jer bi dozvolio veću slobodu u odabiru prijelomnih točaka binarnih varijabli.

\subsection{POKAZATELJI USPJEŠNOST POSLOVANJA}

U empirijskim istraživanjima koja se bave demistificiranjem veze između koncentracije vlasništva i performansi poduzeća dvije mjere uspješnosti se javljaju učestalije od ostalih. Počevši od rada Demsetza i Lehna (1985) profitna stopa se javlja kao najkorištenija varijabla u modelima. U kasnijim istraživanjima autori počinju više koristiti Tobinov Q. Dok je računovodstvena stopa profita definirana kao omjer neto prihoda i dioničkog kapitala, Tobinov Q predstavlja omjer tržišne evaluacije tvrtke i ukupnih troškova zamjene cjelokupne imovine promatrane tvrtke u danom trenutku. Stoga, niska vrijednost omjera (ispod I) implicira da je vrijednost imovine tvrtke veća od trenutačne tržišne evaluacije, odnosno podcijenjenost dionice. Analogno tome, visoki Tobinov Q implicira precijenjenost dionice.

Dvije su osnovne razlike u gore navedena dva pokazatelja uspješnosti tvrtkina poslovanja. Iz vremenske perspektive, profitna stopa predstavlja mjeru uspješnosti utemeljenu na postignućima tvrtke $u$ proteklom razdoblju. S druge strane, Tobinov Q predstavlja stav investitora o budućoj profitabilnosti i razvoju tvrtke. Ova činjenica upućuje na veliku osjetljivost ove mjere na burzovne fluktuacije. Druga razlika direktna je posljedica načina računanja ovih vrijednosti i primijenjenih računovodstvenih

\footnotetext{
${ }^{2}$ Logaritmička transformacija menadžerskog vlasništva koja pretvara ograničeni skup mogućih vrijednosti (između o i Ioo\%) u neograničeni česta je praksa u sličnoj literaturi koja se bavi problemima utvrđivanja odnosa između vlasničke koncentracije i uspješnosti poslovanja (Demsetz i Lehn, I985; Himmelberg, 1999; Grosfeld, 2006).
} 
standarda. Primjenom različitih računovodstvenih politika, moguće je umjetno korigirati vrijednost profitne stope što je često čini nepouzdanom mjerom uspješnosti. Međutim, treba naglasiti kako ni Tobinov Q nije imun na ovaj problem u računanju. Kako bi Tobinov Q bio točan, potrebno je imati podatke o tržišnoj evaluaciji tvrtke i ukupnom trošku zamjene cjelokupne imovine tvrtke. Dok je prvi dio, zahvaljujući informacijama s burze, lako dostupan, trošak zamjene imovine nije lako izračunati te je često aproksimiran knjižnom vrijednošću ukupne imovine. Korištenje knjižne vrijednosti imovine ponovno nas vraća na problem nepouzdanosti računovodstvenih podataka i osjetljivost korištene računovodstvene politike i metode.

U ovom istraživanju kao mjere uspješnosti poslovanja bit će korišteni Tobinov Q i povrat na kapital (ROE). Pored toga, pokušat će se definirati efekt vlasničke koncentracije na učinkovitost rada kao manje korištene mjere uspješnosti. Bertrand i Mullainathan (2003) zaključili su kako je u situaciji gdje ne postoji strah od preuzimanja tvrtke, menadžment skloniji povećanju plaća i drugih povlastica radnicima kako bi se izbjegli sukobi s radnicima i sindikatima te tako „kupio“ mir. Koristeći učinkovitost rada kao ovisnu varijablu moguće je provjeriti idu li uistinu veće razine menadžerskog vlasništva u prilog Bertrandovoj i Mullainhathanovoj hipotezi „mirnog života“. Izbor gore navedene tri mjere uspješnosti poslovanja pokrivaju financijski, tržišni i operativni način mjerenja performansi poduzeća.

Povrat na kapital (ROE) je definiran kao omjer neto profita i dioničkog kapitala. Ova mjera govori koliko efikasno se dionički kapital koristi u svrhu donošenja zarade ulagačima. Učinkovitost rada je aproksimirana omjerom ukupnih troškova rada i ukupnih prihoda. Ova dva indikatora mogu se koristiti na cjelokupnom uzorku. U slučaju Tobinovog Q, iz uzorka će biti izbačene nelikvidne dionice bez varijacija u cijeni. Razlog izbacivanja nelikvidnih tvrtki u slučaju korištenja Tobinovog Q je što u slučaju izuzetno rijetkog trgovanja dionicama određene tvrtke, ova mjera uspješnosti ne predstavlja dovoljno pouzdanu informaciju o tržišnoj evaluaciji dionice.

Tablica 2 opisuje kretanje tri korištena pokazatelja uspješnosti kroz promatrano razdoblje. Medijan je korišten umjesto proste aritmetičke sredine kako bi se neutralizirali efekti ekstremnih vrijednosti u uzorku. Učinkovitost rada manje je sklona ekstremnim vrijednostima te su medijan i aritmetička sredina vrlo slični kroz cijelo promatrano razdoblje.

\section{TABLICA 2.}

Vrijednosti medijana korištenih pokazatelja uspješnosti kroz promatrana razdoblja

\begin{tabular}{lrrrrrrr}
\hline & $\mathbf{2 0 0 3 .}$ & $\mathbf{2 0 0 4}$ & $\mathbf{2 0 0 5 .}$ & $\mathbf{2 0 0 6 .}$ & $\mathbf{2 0 0 7 .}$ & $\mathbf{2 0 0 8 .}$ & $\mathbf{2 0 0 9 .}$ \\
\hline ROE & $\mathrm{I}, 24$ & $\mathrm{I}, 46$ & $\mathrm{I}, 77$ & 2,52 & 2,24 & 0,57 & 0,03 \\
\hline Tobinov Q & $\mathrm{O}, 25$ & $\mathrm{O}, 36$ & $\mathrm{O}, 44$ & 0,64 & 0,82 & $0,3 \mathrm{I}$ & 0,29 \\
\hline Učinkovitost rada & $\mathrm{O}, 22$ & $\mathrm{O}, 2 \mathrm{I}$ & $\mathrm{O}, 23$ & 0,23 & 0,22 & $0,2 \mathrm{I}$ & 0,23 \\
\hline
\end{tabular}

Medijan povrata na kapital ima prilično snažan rast sve do 2006. te nakon usporavanja rasta u 2007, bilježi veliki pad u 2008. da bi godinu kasnije bio gotovo na nuli. Tobinov Q ima nešto stabilniji obrazac kretanja, ali također bilježi veliki pad 20o8. Ovaj pad očigledno je uvjetovan velikim padom cijena dionica kao posljedice svjetske financijske krize. S druge strane, učinkovitost rada je relativno stabilna 
kroz cijelo promatrano razdoblje. Moguće objašnjenje je da s padom prihoda tvrtke počinju otpuštati radnike time smanjujući troškove rada, čime utječu na stabilnost ovog pokazatelja.

\subsection{KONTROLNE VARIJABLE}

Dodatne varijable trebaju biti uključene u regresijske jednadžbe kako bi se kontrolirala mogućnost da drugi faktori, osim vlasničke strukture, utječu na uspješnost poslovanja. Varijabla Poluga je prirodni logaritam udjela vanjskog kapitala u ukupnom financiranju imovine tvrtke. Menadžment se može koristiti visokom polugom kako bi pokrenuo velike investicije i povećao imovinu dioničara. Međutim, u slučaju krive procjene troškovi kamata i kreditni rizik mogu i smanjiti imovinu dioničara. Veličina tvrtke također može utjecati na njene performanse budući da velike tvrtke često uživaju prednosti ekonomije razmjera. U radu se koristi kao aproksimacija za veličinu tvrtke prirodni logaritam ukupnog broja radnika. Potrebno je naglasiti kako su bile uzete u obzir i druge mogućnosti za mjerenje veličine tvrtke kao što su ukupni prihodi ili ukupna imovina, ali broj zaposlenih se pokazao kao mjera koja daje statistički najsignifikantnije rezultate.

Prateći rad Grosfelda (2006), također je uključena kontrolna varijabla za udio nematerijalne imovine u ukupnoj imovini tvrtke. S obzirom da ova kategorija uključuje patente, licence, softvere i sličnu nematerijalnu imovinu, za očekivati je da su tvrtke s višom vrijednosti ove varijable tehnološki naprednije, imaju veću dodanu vrijednost $u$ procesu proizvodnje, te stoga i bolje pokazatelje uspješnosti. Također, postoji mogućnost da ova varijabla aproksimira investicije $u$ istraživanje i razvoj (R\&D). Kako bih kontrolirao za ovu mogućnosti, u model će biti uključena i varijabla s vremenskim pomakom $t$-I. ${ }^{3}$

Varijabla Strani_2o je binarna varijabla koja ima vrijednost I ukoliko strani državljanin ili poduzeće, ili grupa stranih državljana ili poduzeća, kontrolira više od 20\% glasačkih prava u dioničkom društvu. Kao u slučaju varijable BI_3o, i u ovom slučaju u modelu su korištene višestruke vrijednosti prijelomne točke (20, 30 i 40\%). Koeficijenti su u sva tri slučaja bili približno jednaki. Relativno najveći broj jedinica promatranja u slučaju korištenja 20\% kao prijelomne točke glavni je argument u odabiru upravo ove vrijednosti. Za očekivati je da će ova varijabla uglavnom imati pozitivan utjecaj na uspješnost poslovanja. Međutim, kao posljedica kasnog ulaska stranog kapitala na hrvatsko tržište, kada je većina ponajboljih tvrtki već bila privatizirana od strane domaćih poduzetnika, može rezultirati i drugačijim koeficijentima. Kao alternativu ovoj varijabli, u modelu se koriste i binarne varijable Strani_I i Strani_2 koje imaju vrijednost I ukoliko je prvi (drugi) najveći vlasnik strani državljanin ili poduzeće, te nula ukoliko to nije slučaj.

Osnig9ı je binarna varijabla koja uzima vrijednost I ukoliko je tvrtka osnovana prije I99I. te je stoga barem djelomično prošla kroz proces privatizacije. U skladu sa sličnom literaturom, definirana su četiri tipa vanjskih vlasnika: obitelj ili pojedinac, druga tvrtka, država ili financijska institucija. Tipovi vlasništva su binarne varijable koje imaju vrijednost I ukoliko je vlasnik obitelj/tvrtka/država/financijska institucija te nula ukoliko to nije slučaj. Kao referentna vrijednost

\footnotetext{
${ }^{3}$ Pretpostavka je da će ulaganja u R\&D imati utjecaj na uspješnost tek u budućem razdoblju.
} 
postavljeno je vlasništvo druge tvrtke. Anderson (2003) u svom istraživanju pruža dokaze o superiornosti obiteljskog vlasništva nad drugim tipovima vlasništva. Druga krajnost je državno vlasništvo koje se u većini radova, uključujući Grosfeld (2005), pokazuje kao inferiorno u odnosu na sve druge tipove. Bazirajući očekivanja prema spomenutoj literaturi, za očekivati je pozitivan efekt obiteljskog vlasništva te negativan efekt državnog tipa vlasništva na performanse poduzeća.

U svim panel-regresijama korištene su binarne varijable za sve godine promatranog razdoblja. Vremenske binarne varijable su uključene kako bi se kontrolirali potencijalni makroekonomski efekti koji utječu na sve tvrtke u uzorku. Mehanizam za kontrolu makroekonomskog okruženja nužan je u uvjetima makroekonomskih šokova koji su posebno prisutni pri kraju promatranog razdoblja.

Konačno, u model su uključeni i fiksni efekti za sve promatrane tvrtke. Razlog tomu je što na Zagrebačkoj burzi nije moguće kontrolirati pripadnost tvrtki određenim gospodarskim sektorima, jer bi se u nekim sektorima našle svega jedna ili dvije tvrtke.

\section{MetodologijA}

U ovom poglavlju povrat na kapital, Tobinov Q i mjera za učinkovitost rada uključene su u regresijske jednadžbe s varijablama za vlasničku strukturu i ostalim, u prethodnom poglavlju navedenim, kontrolnim varijablama. U prvom dijelu u fokus je stavljeno menadžersko vlasništvo a potom i vlasništvo vanjskih dioničara.

U radu se koristi panel analiza podataka. Po svojoj konstrukciji, panel podaci omogućavaju kontrolu nad potencijalnom heterogenosti. Panel metoda s fiksnim efektima je relevantna u situaciji kada je aritmetička sredina promatranih ovisnih varijabli, u ovom slučaju povrata na kapital, Tobinovog Q i učinkovitosti rada, različita za sve tvrtke u svim razdobljima, s konstantnom varijancom statističkih grešaka (Asteriou, 2006). Fiksiranje vremenskih razdoblja je bitno kako bi se pod kontrolom držali efekti makroekonomskih šokova, posebno prisutnih u posljednje tri godine promatranog razdoblja. Fiksiranje efekata pojedinačnih tvrtki omogućava kontroliranje specifičnih efekata svake pojedinačne tvrtke u uzorku. Ovo je osobito važno s obzirom na već spomenutu nemogućnost kontroliranja pripadnosti tvrtki određenim industrijskim granama s obzirom na relativno mali broj tvrtki izlistanih na Zagrebačkoj burzi.

\section{I MENADŽERSKO VLASNIŠTVO}

Pri istraživanju utjecaja koncentracije menadžerskog vlasništva na uspješnosti poslovanja tvrtki, obično se izdvajaju dva međusobno suprotstavljena efekta koji se mogu opisati kao aktivni i pasivni. Sve dok menadžment nije dovoljno moćan prevladava aktivni efekt koji potiče menadžment na ulaganje više rada i truda u upravljanje tvrtkom. Kako bi očuvali svoju poziciju, menadžeri moraju uvjeriti dioničare, koje predstavlja nadzorni odbor, kako se tvrtka u danoj situaciji vodi na najbolji mogući način. Stoga je za očekivati da će pokazatelji uspješnosti poduzeća rasti sve do točke u kojoj menadžment postaje dovoljno moćan te počne svoje interese pretpostavljati interesima vanjskih 
dioničara. Nakon ove točke, menadžment postaje pasivniji u smislu ostvarivanja dobrobiti za dioničare te se očekuje da će koeficijent menadžerskog vlasništva imati negativan utjecaj na performanse tvrtke. Ova teoretska nelinearna veza između menadžerskog vlasništva je empirijski potvrđena od strane mnogih autora. Međutim, velika većina istraživanja obavljena je na uzorku tvrtki iz SAD-a gdje je vlasnička struktura vrlo disperzirana u odnosu na europska tržišta (La Porta, Lopez-de-Silanes i Shleifer, 1988).

Koristeći panel podatke za razdoblje 2003-o9. s ROE u ulozi ovisne varijable dobiveni su rezultati predstavljeni u tablici 3. Regresijska funkcija (I) uzima u obzir menadžersko vlasništvo kao jedinu varijablu koja objašnjava varijacije u povratu na kapital promatranih tvrtki. Regresijska funkcija (2) pokušava utvrditi postojanje nelinearnosti u odnosima između dvije varijable, ali rezultati su statistički nesignifikantni. Regresijska funkcija (3) uključuje kontrolne varijable koje bi mogle utjecati na vrijednost povrata na kapital, dok četvrta regresija dozvoljava različite efekte različitim predefiniranim tipovima vlasnika. U posljednjem stupcu regresija je gotovo identična regresiji pod (4), s tim da je kvadrirana vrijednost logaritma udjela menadžmenta u ukupnom vlasništvu isključena iz modela.

TABLICA 3.

Panel analiza s fiksnim efektima: utjecaj menadžerskog vlasništva na ROE

\begin{tabular}{|c|c|c|c|c|c|}
\hline & (I) & (2) & (3) & (4) & (5) \\
\hline Lmanager & $\begin{array}{l}-0,015 \\
(0,029)\end{array}$ & $\begin{array}{c}0,042 \\
(0,059)\end{array}$ & $\begin{array}{c}\text { O,IO2 } \\
(0,124) \\
\end{array}$ & $\begin{array}{l}\text { O,IO5 } \\
(\mathrm{O}, \mathrm{I} 2 \mathrm{I}) \\
\end{array}$ & $\begin{array}{c}0,049 \\
(0,048)\end{array}$ \\
\hline Lmanager^2 & & $\begin{array}{l}-0,019 \\
(0,020)\end{array}$ & $\begin{array}{l}-\mathrm{O}, \mathrm{OI} 3 \\
(\mathrm{O}, \mathrm{O} 35) \\
\end{array}$ & $\begin{array}{l}\text {-0,0I9 } \\
(0,036)\end{array}$ & \\
\hline Veličina tvrtke & & & $\begin{array}{c}0,860^{*} \\
(0,267)\end{array}$ & $\begin{array}{c}0,790^{*} \\
(0,294)\end{array}$ & $\begin{array}{c}0,794^{* * *} \\
(0,294)\end{array}$ \\
\hline Veličina tvrtke^2 & & & $\begin{array}{l}-\mathrm{O}, \mathrm{IO5}^{*} \\
(\mathrm{O}, \mathrm{O} 26)\end{array}$ & $\begin{array}{l}-0,099^{*} \\
(0,027)\end{array}$ & $\begin{array}{l}-0,099^{* * *} \\
(0,027)\end{array}$ \\
\hline Poluga & & & $\begin{array}{l}-2,924^{* * *} \\
(\mathrm{I}, 7 \mathrm{O} 2)\end{array}$ & $\begin{array}{l}-3,04 O^{* *} \\
(1,759)\end{array}$ & $\begin{array}{l}-3,044^{* *} \\
(I, 758)\end{array}$ \\
\hline $\begin{array}{l}\text { Nematerijalna } \\
\text { imovina }(\mathrm{t}-\mathrm{I})\end{array}$ & & & $\begin{array}{c}2,564^{*} \\
(\mathrm{I}, 683)\end{array}$ & $\begin{array}{c}2,56 \mathrm{I}^{*} \\
(\mathrm{I}, 678)\end{array}$ & $\begin{array}{c}2,587^{*} \\
(\mathrm{I}, 58 \mathrm{I})\end{array}$ \\
\hline Osnig9I & & & $\begin{array}{c}0,792 \\
(0,648)\end{array}$ & $\begin{array}{c}0,804 \\
(0,654)\end{array}$ & $\begin{array}{c}0,807 \\
(0,654)\end{array}$ \\
\hline Strani_20 & & & $\begin{array}{l}-0,356^{*} \\
(0,22 \mathrm{I})\end{array}$ & $\begin{array}{c}-0,34 \mathrm{I}^{*} \\
(0,244)\end{array}$ & $\begin{array}{l}-0,344^{*} \\
(0,222)\end{array}$ \\
\hline Država & & & & $\begin{array}{c}\text { O,I35 } \\
(\mathrm{O}, \mathrm{I} 5 \mathrm{I}) \\
\end{array}$ & $\begin{array}{c}\text { O,I44 } \\
(0,152) \\
\end{array}$ \\
\hline Fin_inst & & & & $\begin{array}{c}0,542 \\
(0,469)\end{array}$ & $\begin{array}{c}0,555 \\
(0,477)\end{array}$ \\
\hline Obitelj & & & & $\begin{array}{c}0,3 \mathrm{OI} \\
(0,29 \mathrm{I})\end{array}$ & $\begin{array}{c}0,276 \\
(0,279)\end{array}$ \\
\hline R-kvadrat (\%) & 23 & 23 & 30 & 30 & 30 \\
\hline $\mathbf{N}$ & 746 & 746 & 634 & 634 & 634 \\
\hline
\end{tabular}

Efekt menadžerskog vlasništva na ROE je negativan samo u najjednostavnijoj regresijskoj jednadžbi, uz napomenu da je standardna greška gotovo dva puta veća od vrijednosti koeficijenta. U daljnjim regresijama, koeficijent je pozitivan, ali u svakom slučaju nesignifikantan. Iako nije zabilježen statistički signifikantan efekt menadžerskog vlasništva na ROE, panel analiza ukazuje na signifikantnu nelinearnu vezu između veličine tvrtke i njene uspješnosti mjerene povratom na kapital. Prvo, rast tvrtke, u smislu 
rasta broja zaposlenih, pozitivno utječe na poslovanje, a nakon određene točke svaki dodatni radnik počinje negativno djelovati na visinu povrata na kapital. Korištenje zaduživanja u širenju poslovanja ima jak negativan efekt na ROE, po intenzitetu sličan jakom pozitivnom efektu udjela nematerijalne imovine u ukupnoj imovini poduzeća. Interesantno je da koeficijent ispred varijable Strani_2o ima negativan predznak. Ovaj rezultat može djelomično biti objašnjen procesom privatizacije o čemu će biti više riječi u sljedećem poglavlju.

Regresije s Tobinovim Q kao ovisnom varijablom daju rezultate slične prethodnima. Iako je koeficijent ispred varijable Lmanager uvijek negativan, za razliku od regresija s ROE gdje je gotovo uvijek pozitivan, još uvijek je nesignifikantan na bilo kojoj statistički prihvatljivoj razini. Možemo zaključiti kako ni u slučaju Tobinovog Q, menadžersko vlasništvo nema utjecaja na uspješnost poslovanja tvrtki sa Zagrebačke burze. Međutim, ponovno su zabilježena dva interesantna detalja vezana uz kontrolne varijable. Tvrtke osnovane prije 199ı. imaju pozitivan koeficijent što nam govori kako su investitorima u prosjeku interesantnije od tvrtki osnovanih nakon osamostaljenja Hrvatske.

TABLICA 4.

Panel analiza s fiksnim efektima: utjecaj menadžerskog vlasništva na Tobinov Q

\begin{tabular}{|c|c|c|c|c|c|}
\hline & (I) & (2) & (3) & (4) & (5) \\
\hline Lmanager & $\begin{array}{l}-0,016 \\
(0,032) \\
\end{array}$ & $\begin{array}{l}-\mathrm{O}, \mathrm{OI} 4 \\
(\mathrm{O}, \mathrm{O} 7 \mathrm{I}) \\
\end{array}$ & $\begin{array}{l}-0,043 \\
(0,088) \\
\end{array}$ & $\begin{array}{l}-0,077 \\
(0,088) \\
\end{array}$ & $\begin{array}{l}-\mathrm{O}, \mathrm{O} 2 \mathrm{I} \\
(\mathrm{O}, \mathrm{O} 33) \\
\end{array}$ \\
\hline Lmanager^2 & & $\begin{array}{l}\text { O,006 } \\
(0,019)\end{array}$ & $\begin{array}{c}\text { O,OI4 } \\
(0,027)\end{array}$ & $\begin{array}{c}\mathrm{O}, \mathrm{O} 2 \mathrm{I} \\
(\mathrm{O}, \mathrm{O} 27)\end{array}$ & \\
\hline Veličina tvrtke & & & $\begin{array}{c}\text { O,IO7 } \\
(0,086) \\
\end{array}$ & $\begin{array}{l}\text { O,O46 } \\
(0, I O I)\end{array}$ & $\begin{array}{c}0,044 \\
(0,099)\end{array}$ \\
\hline Veličina tvrtke^2 & & & $\begin{array}{l}\text {-O,OI7 } \\
\text { (0,0I6) }\end{array}$ & $\begin{array}{l}-0,009 \\
(0,017)\end{array}$ & $\begin{array}{l}-0,009 \\
(0,017)\end{array}$ \\
\hline Poluga & & & $\begin{array}{l}-0,653^{* *} \\
(0,264)\end{array}$ & $\begin{array}{l}-0,773^{* * *} \\
(0,265)\end{array}$ & $\begin{array}{l}-0,769^{* * *} \\
(0,265)\end{array}$ \\
\hline $\begin{array}{l}\text { Nematerijalna } \\
\text { imovina (t-I) }\end{array}$ & & & $\begin{array}{l}-\mathrm{I}, 036 \\
(0,992) \\
\end{array}$ & $\begin{array}{c}\mathrm{O}, 85 \mathrm{I} \\
(\mathrm{O}, 92 \mathrm{I}) \\
\end{array}$ & $\begin{array}{c}0,792 \\
(0,998) \\
\end{array}$ \\
\hline Osni99I & & & $\begin{array}{l}0,474^{* * *} \\
(0,087)\end{array}$ & $\begin{array}{l}0,487^{* * *} \\
(0,086)\end{array}$ & $\begin{array}{l}0,485^{* * *} \\
(0,086)\end{array}$ \\
\hline Strani_20 & & & $\begin{array}{l}\text {-O,I66* } \\
\text { (o,IOI) } \\
\end{array}$ & $\begin{array}{l}-\mathrm{O}, \mathrm{I} 32 \\
(\mathrm{O}, \mathrm{II} 3) \\
\end{array}$ & $\begin{array}{l}-\mathrm{O}, \mathrm{I} 32 \\
(\mathrm{O}, \mathrm{II} 3) \\
\end{array}$ \\
\hline Država & & & & $\begin{array}{c}0,227 \\
(0,048)\end{array}$ & $\begin{array}{c}0,226 \\
(0,047)\end{array}$ \\
\hline Fin_Inst & & & & $\begin{array}{l}\text { O,522*** } \\
(0, I 49)\end{array}$ & $\begin{array}{l}\text { O,5OI*** } \\
(\mathrm{O}, \mathrm{I} 48)\end{array}$ \\
\hline Obitelj & & & & $\begin{array}{r}0,185^{*} \\
(0,099) \\
\end{array}$ & $\begin{array}{c}\text { O,I92** } \\
(0,097)\end{array}$ \\
\hline R- kvadrat (\%) & 69 & 69 & $7 \mathrm{I}$ & $7 \mathrm{I}$ & $7 \mathrm{I}$ \\
\hline $\mathbf{N}$ & 446 & 446 & $4 \mathrm{O} 3$ & 403 & 403 \\
\hline
\end{tabular}

***, **, $i$ * označavaju razinu statističke signifikantnosti od I\%, 5\% i Io\%.

N obilježava broj jedinica promatranja.

Standardne greške su u zagradama.

Moguće objašnjenje ovog efekta je da su stare tvrtke izlistane danas na Burzi ustvari podskup najboljih i najjačih tvrtki osnovanih prije I99I, koje su, nadalje, započele svoj razvoj na tržištu koje je bilo značajno veće od današnjeg unutarnjeg tržišta Hrvatske. Te su tvrtke u velikom broju slučajeva zadržale poslovne kontakte i imaju razvijen brand u susjednim zemljama što im omogućava lakše širenje i pristup većem broju klijenata. Tvrtke iz ove grupe bile su dovoljno snažne da opstanu u ratnom razdoblju i uspješno prođu kroz proces privatizacije što ukazuje na problem neravnomjerne selekcije 
uzorka s obzirom da su slabije stare tvrtke nestale s tržišta utječući na pozitivnost koeficijenta u panel regresiji.

Tvrtke sa značajnim udjelom stranog vlasništva još jednom imaju negativan koeficijent, iako signifikantan samo u regresijskoj funkciji (3). Ovaj rezultat može biti djelomično opravdan procesom privatizacije. Većina privatizacije u Hrvatskoj je izvršena tijekom i odmah nakon rata kad je interes međunarodnih investitora za Hrvatsku, u odnosu na druge postkomunističke zemlje poput Madžarske i Češke, bio nizak. Nakon 1999. godine kada strani kapital u sve većim količinama dolazi u Hrvatsku, ponajbolje tvrtke već su pronašle svog vlasnika među domaćim investitorima.

Nadalje, tvrtke čiji je najveći vlasnik financijska institucija imaju značajno veću vrijednost Tobinovog Q. Utjecaj udjela nematerijalne imovine na performanse je u ovom slučaju nejasan, dajući do znanja kako tehnološki usmjerene tvrtke, iako superiorne u smislu povrata na kapital, nisu nužno privlačnije investitorima.

U slučaju kada je ovisna varijabla učinkovitost rada, panel analiza s fiksnim efektima otkriva kako je varijabla Lmanager $\mathrm{u}$ negativnoj korelaciji $\mathrm{s}$ uspješnošću tvrtkina poslovanja. Koeficijent je signifikantan na razini od Io\%. Ovaj rezultat blaga je potvrda Bertrandove (2003) hipoteze o „mirnom životu“ menadžmenta. Onog trenutka kad menadžment postane dovoljno neovisan i snažan, radije će pribjeći neopravdanom povećanju primanja zaposlenika nego ulaziti u konflikte sa sindikatima i riskirati mogućnost štrajka. Učinkovitost rada stoga opada, ali bez opasnosti od smjene ili preuzimanja, menadžeri mogu uživati „miran život“.

Koeficijent za veličinu tvrtke je nesignifikantan i ne pokazuje znakove nelinearnosti. Nematerijalna imovina ima pozitivan efekt na učinkovitost rada, ali je marginalno signifikantna samo u regresijskoj funkciji (5). Stare tvrtke su efikasnije od onih osnovanih nakon 199ı. Potrebno je imati u vidu da je riječ uglavnom o najsnažnijim tvrtkama s razgranatom mrežom i poslovima $u$ svim državama bivše Jugoslavije. Tvrtke čiji je najveći dioničar država očekivano su neefikasnije, a obiteljske tvrtke efikasnije u odnosu na baznu vrijednost. Državne tvrtke često pripadaju tradicionalnim i radno intenzivnim industrijama. Nadalje, Vlada je često vrlo neodlučna u otpuštanju viška radnika jer su politički ciljevi vrlo često iznad ekonomskih. S druge strane, obiteljske tvrtke su orijentirane na profit, tim više što je ista obično glavni izvor prihoda obitelji. Stoga, ove tvrtke imaju veći poticaj ostvarivati najveću moguću efikasnost rada, ne upošljavati dodatnu radnu snagu ukoliko to doista nije potrebno, te ne davati plaće više od onih za koje vlasnici smatraju da su optimalne. 
TABLICA 5.

Panel analiza s fiksnim efektima: utjecaj menadžerskog vlasništva na učinkovitost rada

\begin{tabular}{|c|c|c|c|c|c|}
\hline & (I) & (2) & (3) & (4) & (5) \\
\hline Lmanager & $\begin{array}{l}-0,065 \\
(0,068)\end{array}$ & $\begin{array}{l}-\mathrm{O}, \mathrm{I} 74 \\
(\mathrm{O}, \mathrm{II} 3)\end{array}$ & $\begin{array}{l}-0,254^{*} \\
(0,152)\end{array}$ & $\begin{array}{l}-0,256^{*} \\
(0,145)\end{array}$ & $\begin{array}{c}-\mathrm{O}, \mathrm{I} 49^{*} \\
(\mathrm{o}, \mathrm{O} 89)\end{array}$ \\
\hline Lmanager^2 & & $\begin{array}{c}0,036 \\
(0,022)\end{array}$ & $\begin{array}{c}\mathrm{O}, \mathrm{O} 47 \\
(\mathrm{O}, \mathrm{O} 3 \mathrm{I})\end{array}$ & $\begin{array}{c}0,035 \\
(0,025)\end{array}$ & \\
\hline Veličina tvrtke & & & $\begin{array}{c}0,597 \\
(0,584)\end{array}$ & $\begin{array}{c}0,579 \\
(0,469)\end{array}$ & $\begin{array}{c}0,579 \\
(0,544) \\
\end{array}$ \\
\hline Velicina tvrtke^2 & & & $\begin{array}{l}-0,056 \\
(0,05 I)\end{array}$ & $\begin{array}{l}-0,054 \\
(0,042)\end{array}$ & $\begin{array}{l}-0,053 \\
(0,047)\end{array}$ \\
\hline Poluga & & & $\begin{array}{l}-\mathrm{O}, \mathrm{I} 67 \\
(\mathrm{O}, \mathrm{I} 4 \mathrm{I})\end{array}$ & $\begin{array}{l}-0, I 32 \\
(0, I 59)\end{array}$ & $\begin{array}{l}- \text { O,II9 } \\
(0, I 38)\end{array}$ \\
\hline $\begin{array}{l}\text { Nematerijalna } \\
\text { imovina (t-I) }\end{array}$ & & & $\begin{array}{l}0,5 \mathrm{OI} \\
(0,363)\end{array}$ & $\begin{array}{c}0,486 \\
(0,404)\end{array}$ & $\begin{array}{c}0,545^{*} \\
(0,334)\end{array}$ \\
\hline Osnig9I & & & $\begin{array}{l}0,576^{* * *} \\
(0,087)\end{array}$ & $\begin{array}{l}\text { O,544*** } \\
(0,107)\end{array}$ & $\begin{array}{l}\text { O,544*** } \\
(\mathrm{O}, \mathrm{II} 8)\end{array}$ \\
\hline Strani_20 & & & $\begin{array}{l}0,008 \\
(0,029)\end{array}$ & $\begin{array}{c}0,05 \mathrm{I} \\
(0,053)\end{array}$ & $\begin{array}{l}0,049 \\
(0,053)\end{array}$ \\
\hline Država & & & & $\begin{array}{l}-0,275^{*} \\
(0,167)\end{array}$ & $\begin{array}{l}-0,244^{*} \\
(0,15 I)\end{array}$ \\
\hline Fin_Inst & & & & $\begin{array}{l}-\mathrm{O}, \mathrm{I} 29 \\
(\mathrm{O}, \mathrm{I} 23)\end{array}$ & $\begin{array}{l}-0, I 54 \\
(0,125)\end{array}$ \\
\hline Obitelj & & & & $\begin{array}{c}\text { O,297* } \\
(0,196)\end{array}$ & $\begin{array}{c}\mathrm{O}, 3 \mathrm{I} 2^{*} \\
(\mathrm{O}, \mathrm{I} 86)\end{array}$ \\
\hline R-kvadrat (\%) & 76 & 76 & 78 & 79 & 79 \\
\hline $\mathbf{N}$ & 744 & 744 & 633 & 633 & 633 \\
\hline
\end{tabular}

\subsection{POSTOJANJE VELIKOG DIONIČARA}

Jedna od najuvriježenijih teorija jest da koncentracija vlasništva u rukama jednog ili manje grupe dioničara poboljšava mjerljive pokazatelje uspješnosti poduzeća, ponajviše zbog povećanog nadzora $\mathrm{i}$ kontrole menadžmenta (Shleifer i Vishny, I986; McConnel i Servael, I990; Zingales, 1996; Claessens i Djankov, 1998). Mali dioničari često nemaju dovoljno snažan motiv vršiti nadzor menadžmenta $\mathrm{s}$ obzirom da su troškovi istog često veći od potencijalne koristi. S druge strane, dovoljno veliki dioničar, kroz povećanje vrijednosti dioničkog kapitala, može pokriti troškove nadzora.

S druge strane, postoji struja autora koja tvrdi kako veza između uspješnosti poduzeća i postojanja velikog dioničara nije tako jednostavna, te varira ovisno o zakonskom uređenju države te karakteristikama same tvrtke (Demsetz i Lehn, 1985). Također, u državama koje zakonski nedovoljno štite male dioničare, postojanje velikih vlasnika može smanjiti likvidnost burzovnog trgovanja, učiniti tvrtke manje interesantnim malim ulagačima, te time smanjiti njihovu tržišnu kapitalizaciju, što bi drugim riječima značilo negativnu korelaciju postojanja velikog vlasnika s vrijednošću Tobinovog Q.

Panel analiza s fiksnim efektima ne upućuje na postojanost statistički signifikantne veze između velikog dioničara i vrijednosti povrata na kapital (tablica 6). Samo u slučaju kada je veliki dioničar financijska institucija, koeficijent je signifikantan na razini od 5\%. U regresijskim funkcijama (2) i (3) poluga ima snažan negativan efekt, dok je efekt nematerijalne imovine pozitivan i signifikantan samo u 
trećoj regresiji kad su u model uključene kontrole za tipove vlasnika. Strano vlasništvo je još jednom u negativnom, ali nesignifikantnom odnosu s uspješnošću poduzeća.

TABLICA 6.

Panel analiza s fiksnim efektima: utjecaj velikog vlasnika na ROE

\begin{tabular}{|c|c|c|c|}
\hline & $(\mathrm{I})$ & (2) & (3) \\
\hline BI_30 & $\begin{array}{c}\text { O,IIO } \\
(0, I 23)\end{array}$ & $\begin{array}{l}\text { O,09I } \\
(0,167)\end{array}$ & $\begin{array}{c}-0,050 \\
(0, I 3 I)\end{array}$ \\
\hline Veličina tvrtke & & $\begin{array}{c}0,856^{*} \\
(0,506)\end{array}$ & $\begin{array}{c}0,830^{*} \\
(0,494)\end{array}$ \\
\hline Veličina tvrtke^2 & & $\begin{array}{l}-0, \mathrm{IO}^{* *} \\
(0,058)\end{array}$ & $\begin{array}{l}-\mathrm{O}, \mathrm{IO} 4 \\
(\mathrm{O}, \mathrm{O} 32)\end{array}$ \\
\hline Poluga & & $\begin{array}{l}-2,844^{* * *} \\
(\mathrm{I}, 678)\end{array}$ & $\begin{array}{l}-2,983^{* *} \\
(\mathrm{I}, 479)\end{array}$ \\
\hline $\begin{array}{l}\text { Nematerijalna } \\
\text { imovina (t-I) }\end{array}$ & & $\begin{array}{c}2,649 \\
(2,045) \\
\end{array}$ & $\begin{array}{l}2,674^{* *} \\
(\mathrm{I}, 22 \mathrm{I})\end{array}$ \\
\hline Osnig9I & & $\begin{array}{c}0,858 \\
(0,644)\end{array}$ & $\begin{array}{c}0,85 \mathrm{I} \\
(0,646)\end{array}$ \\
\hline Strani_20 & & $\begin{array}{l}-0,492 \\
(0,378) \\
\end{array}$ & $\begin{array}{l}-0,448 \\
(0,419) \\
\end{array}$ \\
\hline Država & & & $\begin{array}{c}\text { O,I67 } \\
(0,192) \\
\end{array}$ \\
\hline Fin_Inst & & & $\begin{array}{c}0,598^{* *} \\
(0,265)\end{array}$ \\
\hline Obitelj & & & $\begin{array}{c}0,283 \\
(0,330) \\
\end{array}$ \\
\hline R-kvadrat (\%) & 23 & 29 & 30 \\
\hline $\mathbf{N}$ & 746 & 634 & 634 \\
\hline
\end{tabular}

Panel regresija ukazuje na signifikantnu negativnu vezu između varijabli BI_3o i vrijednosti Tobinovog Q (tablica 7). Postoje dva moguća objašnjenja ove korelacije. Prvi potencijalni uzrok je već spomenuta smanjenja likvidnost dionica na burzi. Drugi razlog je da veliki dioničar može koristiti svoj utjecaj kako bi povećao osobne koristi, kroz primjerice povećanje dividendne isplate, smanjeno reinvestiranje, transfer najprofitabilnijih dijelova poslovanja na druge tvrtke u svom vlasništvu i slično. Koeficijenti kontrolnih varijabli su vrlo slični onima iz prethodnih regresija. Tvrtke koje se financiraju zaduživanjem imaju u prosjeku slabije performanse, a tvrtke osnovane prije ig9I. su interesantnije investitorima. U situaciji kada je najveći dioničar stranac, efekt na Tobinov $Q$ je negativan i signifikantan u regresijskoj funkciji (2), a nakon uključenja varijabli koje definiraju tip vlasnika efekt nestaje.

Prisustvo velikog dioničara ne utječe na učinkovitost rada (tablica 8). Logično je pretpostaviti kako je ova varijabla više pod direktnim utjecajem menadžmenta nego vlasnika. Međutim, ukoliko diferenciramo vlasnike po tipovima, ponovno je uočljiva superiornost obiteljskog nad državnim vlasništvom. Veličina tvrtke slabo objašnjava varijacije u učinkovitosti rada. Poluga ima negativan efekt, ali značajno slabiji nego što je to slučaj s Tobinovim Q i povratom na kapital. Zaključak da su tvrtke osnovane prije I99I. učinkovitije još jednom je potvrđen na razini od ıo\% signifikantnosti. 
TABLICA 7.

Panel analiza s fiksnim efektima: utjecaj velikog vlasnika na Tobinov $Q$

\section{TABLICA 8.}

Panel analiza s fiksnim efektima: utjecaj velikog vlasnika na učinkovitost rada

\begin{tabular}{|c|c|c|c|c|c|c|}
\hline & (I) & (2) & (3) & (I) & (2) & (3) \\
\hline BI_30 & $\begin{array}{l}-0,194^{* *} \\
(0,094)\end{array}$ & $\begin{array}{l}-0,203^{*} \\
(0, I I 7)\end{array}$ & $\begin{array}{l}-0,402^{*} \\
(0,237)\end{array}$ & $\begin{array}{c}\text { O,II5 } \\
(0, I 4 I)\end{array}$ & $\begin{array}{c}\text { O,I88 } \\
(0,284)\end{array}$ & $\begin{array}{c}\mathrm{O}, \mathrm{OOI} \\
(\mathrm{O}, \mathrm{O} 44)\end{array}$ \\
\hline Veličina tvrtke & & $\begin{array}{l}0,204 \\
(0,177) \\
\end{array}$ & $\begin{array}{c}\text { O,I59 } \\
(0,162) \\
\end{array}$ & & $\begin{array}{c}0,579 \\
(0,473) \\
\end{array}$ & $\begin{array}{l}0,447 \\
(0,34) \\
\end{array}$ \\
\hline Veličina tvrtke^2 & & $\begin{array}{l}-0,027 \\
(0,022) \\
\end{array}$ & $\begin{array}{l}-\mathrm{O}, \mathrm{O} 2 \mathrm{I} \\
(\mathrm{O}, \mathrm{O} 2 \mathrm{I}) \\
\end{array}$ & & $\begin{array}{l}-0,055 \\
(0,042) \\
\end{array}$ & $\begin{array}{l}-0,044 \\
(0,030) \\
\end{array}$ \\
\hline Poluga & & $\begin{array}{l}-0,609^{* *} \\
(0,279)\end{array}$ & $\begin{array}{l}-0,795^{* * *} \\
(0,303)\end{array}$ & & $\begin{array}{l}\text {-O,I94*** } \\
(0, \mathrm{IO} 8)\end{array}$ & $\begin{array}{l}-0,308^{* *} \\
(0, I 7 I)\end{array}$ \\
\hline $\begin{array}{l}\text { Nematerijalna } \\
\text { imovina ( } \mathrm{t}-\mathrm{I})\end{array}$ & & $\begin{array}{c}0,694 \\
(0,926)\end{array}$ & $\begin{array}{l}\text { O,4I6 } \\
(0,90)\end{array}$ & & $\begin{array}{c}0,429 \\
(0,34 \mathrm{I})\end{array}$ & $\begin{array}{c}0,319 \\
(0,288)\end{array}$ \\
\hline Osnig9I & & $\begin{array}{c}0,476^{*} \\
(0,087) \\
\end{array}$ & $\begin{array}{l}0,454^{* * *} \\
(0, \mathrm{IO} 3)\end{array}$ & & $\begin{array}{c}0,662^{*} \\
(0,106)\end{array}$ & $\begin{array}{c}\mathrm{O}, 55 \mathrm{I}^{*} \\
(\mathrm{O}, \mathrm{II} 8)\end{array}$ \\
\hline Strani_20 & & $\begin{array}{l}-0,273^{* *} \\
(0, I I 3)\end{array}$ & $\begin{array}{l}-0,139 \\
(0,2 I 2) \\
\end{array}$ & & $\begin{array}{c}-0, I 33 \\
(0,093) \\
\end{array}$ & $\begin{array}{l}\text { O,054 } \\
(0, I I 6) \\
\end{array}$ \\
\hline Država & & & $\begin{array}{c}0,193 \\
(0,482)\end{array}$ & & & $\begin{array}{c}0,673^{* *} \\
(0,398)\end{array}$ \\
\hline Fin_inst & & & $\begin{array}{c}0,742^{* *} \\
(0,369)\end{array}$ & & & $\begin{array}{l}-0,241^{* *} \\
(0,132)\end{array}$ \\
\hline Obitelj & & & $\begin{array}{l}0,349 \\
(0,312) \\
\end{array}$ & & & $\begin{array}{c}0,387 \\
(0,28 \mathrm{I}) \\
\end{array}$ \\
\hline R-kvadrat(\%) & 69 & $7 \mathrm{I}$ & 72 & 75 & 78 & 79 \\
\hline $\mathbf{N}$ & 446 & 403 & 403 & 744 & 633 & 633 \\
\hline
\end{tabular}

***, **, $i$ * označavaju razinu statističke signifikantnosti od I\%, 5\% i Io\%.

N obilježava broj jedinica promatranja.

Standardne greške su u zagradama.

\subsection{POSTOJANJE DRUGOG VELIKOG DIONIČARA}

Ovaj dio rada istražuje pretpostavku kako postojanje drugog velikog dioničara također može imati utjecaja na poslovanje poduzeća. U ovdje korištenom uzorku tvrtki, prosječna vrijednost udjela $u$ dioničkoj glavnici drugog najvećeg dioničara je relativno visokih 12\%. Ukoliko već definirani negativan utjecaj postojanja prvog velikog dioničara na Tobinov Q pripišemo smanjenoj likvidnosti, onda je za očekivati da će koeficijent za drugog velikog dioničara također biti negativan. Broj dionica u slobodnom optjecaju je još manji u tom slučaju, a time i likvidnost trgovanja. Međutim, ukoliko negativan utjecaj velikog dioničara na Tobinov Q dolazi od činjenice da isti koristi svoju moć i utjecaj na prisvajanje dodatnih pogodnosti i ostvarivanje vlastitih interesa, očekivani rezultat regresije je drugačiji. U slučaju da dva vlasnika surađuju i zajedno rade na ostvarivanju vlastitih interesa na štetu malih dioničara očekuje se mali, negativan ili nesignifikantan efekt. Međutim, ukoliko ne postoji suradnja među dva velika vlasnika, drugi vlasnik ima jak motiv vršiti strog nadzor nad poduzećem i ponašanjem prvog velikog dioničara. U tom slučaju koeficijent uz varijablu B2_Io trebao bi imati pozitivnu vrijednost, odnosno očekujemo bolje performanse poduzeća zbog strožeg nadzora velikog dioničara koji više nije u stanju jednostavno si priskrbiti dodatne pogodnosti na štetu ostalih vlasnika. Varijabla B2_Io definirana je kao binarna varijabla koja uzima vrijednost I ukoliko drugi najveći dioničar kontrolira više od ıo\% dioničke glavnice, te nulu ukoliko je njegov udio u vlasništvu ispod ıo\%. Rezultati regresije prikazani su u tablici 9. 
Regresijska funkcija (I) uzima u obzir samo dvije binarne varijable koje pokušavaju utvrditi efekt postojanja prvog i drugog velikog vlasnika. Efekt postojanja velikog dioničara, koji kontrolira preko 30\% kapitala još uvijek je negativan, dok je koeficijent ispred varijable B2_Io statistički nesignifikantan. Regresijska funkcija (2) dodatno uključuje i interakciju između dvije vlasničke varijable, ali efekt je još uvijek nesignifikantan. U trećem stupcu prikazani su rezultati regresijske jednadžbe u koju su uključene i kontrolne varijable za identitet drugog velikog dioničara. Razlog za kontrolu nad identitetom drugog vlasnika je to što je za očekivati da različiti vlasnici nemaju jednako snažan motiv za nadzor rada poduzeća. Obitelj, primjerice, ima puno snažniju motivaciju za aktivno sudjelovanje u radu tvrtke, nego što to ima država za koju se očekuje pasivnost u upravljanju. Regresijska funkcija (4) potvrđuje ta očekivanja. Ukoliko je drugi najveći dioničar obitelj ili pojedinac, prisutan je signifikantan pozitivan efekt koji svojim intenzitetom nadmašuje negativan efekt prvog velikog vlasnika. Država i financijske institucije u ulozi drugog najvećeg dioničara ne utječu značajno na uspješnost poslovanja tvrtki izlistanih na Zagrebačkoj burzi.

TABLICA 9.

Panel analiza s fiksnim efektima: utjecaj drugog velikog vlasnika na Tobinov Q

\begin{tabular}{|c|c|c|c|c|}
\hline & (I) & (2) & (3) & (4) \\
\hline BI_30 & $\begin{array}{l}-\mathrm{O}, 2 \mathrm{O} 2^{*} \\
(0,075)\end{array}$ & $\begin{array}{l}-0, \mathrm{I} 78 \\
(0, \mathrm{I} 22)\end{array}$ & $\begin{array}{c}-\mathrm{O}, \mathrm{I7}^{*} \\
(\mathrm{O}, \mathrm{IO})\end{array}$ & $\begin{array}{l}-\mathrm{O}, 24 \mathrm{I}^{* *} \\
(\mathrm{O}, \mathrm{I} 3 \mathrm{I})\end{array}$ \\
\hline B2_IO & $\begin{array}{c}-0,06 \\
(0,044) \\
\end{array}$ & $\begin{array}{l}-0,043 \\
(0,076) \\
\end{array}$ & $\begin{array}{c}0,06 \\
(0,08) \\
\end{array}$ & $\begin{array}{c}\text { O,OOI } \\
(\mathrm{o}, \mathrm{Oo6}) \\
\end{array}$ \\
\hline Veličina tvrtke & & & $\begin{array}{c}\text { O,2I } \\
(0,19) \\
\end{array}$ & $\begin{array}{l}-\mathrm{O}, \mathrm{OI} 4 \\
(\mathrm{O}, \mathrm{O} 23) \\
\end{array}$ \\
\hline Veličina tvrtke^2 & & & $\begin{array}{l}-\mathrm{O}, \mathrm{O} 3 \\
(\mathrm{O}, \mathrm{O} 3)\end{array}$ & $\begin{array}{l}-0,006 \\
(0,027)\end{array}$ \\
\hline Osnig9I & & & $\begin{array}{c}0,47^{*} \\
(0,09)\end{array}$ & $\begin{array}{l}0,422^{* * *} \\
(0,09)\end{array}$ \\
\hline Poluga & & & $\begin{array}{l}-0,67^{* *} \\
(0,29)\end{array}$ & $\begin{array}{l}-0,64 I^{* *} \\
(0,305)\end{array}$ \\
\hline $\begin{array}{l}\text { Nematerijalna } \\
\text { imovina (t-I) }\end{array}$ & & & $\begin{array}{c}0,84 \\
(I, 93)\end{array}$ & $\begin{array}{l}0,889 \\
(I, 017)\end{array}$ \\
\hline BI_30*B2_IO & & $\begin{array}{l}-0,042 \\
(0,048)\end{array}$ & $\begin{array}{l}\text {-O,I3 } \\
(\mathrm{O}, \mathrm{I} 9)\end{array}$ & \\
\hline Strani_20 & & & $\begin{array}{c}-0,18 \\
(0,08)\end{array}$ & \\
\hline BI*B2*B2_obitelj & & & & $\begin{array}{l}\mathrm{O}, 43 \mathrm{I}^{* * *} \\
(0, \mathrm{I} 53)\end{array}$ \\
\hline BI*B2*B2_fin_inst & & & & $\begin{array}{c}0,074 \\
(0,105) \\
\end{array}$ \\
\hline BI*B2*B2_država & & & & $\begin{array}{l}-0,028 \\
(0,025)\end{array}$ \\
\hline BI*B2*Strani_2 & & & & $\begin{array}{c}-0,184^{*} \\
(0,099)\end{array}$ \\
\hline R-kvadrat (\%) & 69 & 70 & $7 \mathrm{I}$ & 72 \\
\hline $\mathrm{N}$ & 446 & 446 & 403 & 403 \\
\hline
\end{tabular}

N obilježava broj jedinica promatranja.

Standardne greške su u zagradama.

Prema Gugleru i Weigandu (2003), veliki vanjski dioničari utječu na performanse poduzeća egzogeno. Međutim, utjecaj menadžmenta je endogen, što dovodi u pitanje rezultate dobivene panel analizom, o čemu će biti više u sljedećem poglavlju. 


\section{ENDOGENOST}

Najveći dio istraživačkih radova na temu povezanosti vlasničke strukture i uspješnosti poslovanja polazi od pretpostavke da je vlasništvo egzogena varijabla. Međutim, još od rada Demsetza (1983) te Demsetza i Lehna (1985) ustalila se i pretpostavka o endogenosti vlasništva. U tom slučaju, kao što su dokazali Demsetz i Villalonga (200I), rezultati panel analize su neprecizni i često netočni.

Kako bi se ispitao utjecaj potencijalne endogenosti na rezultate panel analize, koristit će se pristupom Guglera i Weiganda (2003). Autori su, koristeći panel podatke iz Njemačke i SAD-a, utvrdili kako je menadžersko vlasništvo u ekonometrijskom smislu endogeno. Rad Guglera i Weiganda zanimljiv je ne samo po tome što je jedan od najcitiranijih radova na ovu temu, nego i zbog toga što se bave uzorkom njemačkih tvrtki. Hrvatsko zakonodavstvo je puno sličnije njemačkom nego SAD-a. Njemačka ekonomija je baš poput hrvatske, okarakterizirana široko rasprostranjenim postojanjem velikih dioničara.

Kako bi se provjerio utjecaj endogenosti menadžerskog vlasništva na rezultate panel analize, ovaj dio empirijskog istraživanja koristi se instrumentaliziranom procjenom koeficijenata pomoću 2SLS metode. Kako bi instrumentalizirana procjena bila relevantna, potrebno je definirati instrumentalnu varijablu koja je $\mathrm{u}$ korelaciji sa potencijalno endogenom varijablom, a egzogena $u$ odnosu na ostale dijelove modela. Himmelberg (1999) tvrdi kako je volatilnost cijena dionica, iako ne savršena, prihvatljiva instrumentalna varijabla. Argument iza ove tvrdnje je da s većom volatilnosti cijena dionica nadzor menadžera i tvrtke postaje skuplji i zahtijeva više truda, ali je i potencijalna dobit veća. S druge strane, kad je okruženje relativno stabilno, dioničari imaju manje teškoća, ali su i manje motivirani vršiti nadzor menadžmenta. Prema tome, za očekivati je da rizičnije tvrtke (one s većom volatilnosti cijena dionica) s vremenom dobiju koncentriraniju vlasničku strukturu. Koristeći podatke o dnevnom trgovanju na Zagrebačkoj burzi izračunate su varijance i standardne devijacije cijena dionica iz uzorka. Međutim, pokazalo se kako one nisu u korelaciji s menadžerskim vlasništvom te su stoga isključene iz izbora za instrumentalne varijable.

Druga mogućnost je korištenje vrijednosti kontrolnih varijabli s vremenskim pomakom kao instrumente za menadžersko vlasništvo (Hermalin i Weisbach, 199I). Rezultati 2SLS analize povrata na kapital i učinkovitosti rada, instrumentalizirane vrijednostima kontrolnih varijabli iz $t$-I razdoblja prikazani su u tablici Io. Prije diskutiranja rezultata potrebno je napomenuti potencijalnu slabu točku ove vrste analize. Ukoliko su glavni izvor endogenosti u ovom modelu nekontrolirane karakteristike tvrtki, i ukoliko su promjenjive ovisno o razdoblju promatranja, onda će $t$-I vrijednosti varijabli također biti pod utjecajem endogenosti.

Rezultati 2SLS analize pokazuju kako ne postoji utjecaj menadžerskog vlasništva na povrat na kapital i vrijednost Tobinovog Q. Međutim, rezultat koji pokazuje kako viša koncentracija menadžerskog vlasništva smanjuje učinkovitost rada opstao je i nakon uključenja instrumentalnih varijabli u model te je signifikantan na razini od Io\%. Nadalje, kvadrirana vrijednost menadžerskog vlasništva je 
signifikantna tek na razini od I5\% što znači da model nije zabilježio postojanje nelinearnosti u odnosu između dvije varijable.

TABLICA IO.

2SLS analiza: utjecaj menadžerskog vlasništva na ROE i učinkovitost rada

\begin{tabular}{|c|c|c|c|}
\hline & RHS: učinkovitost rada & RHS: povrat na kapital & RHS: Tobinov Q \\
\hline Lmanager & $\begin{array}{l}-0,5 \mathrm{I} 8^{*} \\
(0,29 \mathrm{I}) \\
\end{array}$ & $\begin{array}{c}0,239 \\
(0,253) \\
\end{array}$ & $\begin{array}{c}0,044 \\
(0,038) \\
\end{array}$ \\
\hline Lmanager^2 & $\begin{array}{c}\text { O,III } \\
(0,07 \mathrm{I})\end{array}$ & $\begin{array}{l}-0,049 \\
(0,069) \\
\end{array}$ & $\begin{array}{l}-\mathrm{O}, \mathrm{O} 3 \mathrm{I} \\
(\mathrm{O}, \mathrm{O} 52) \\
\end{array}$ \\
\hline Veličina tvrtke & $\begin{array}{c}0,538 \\
(0,522)\end{array}$ & $\begin{array}{c}0,883^{*} \\
(0,548)\end{array}$ & $\begin{array}{c}\text { O,III } \\
(\text { O,II5) }\end{array}$ \\
\hline Veličina tvrtke^2 & $\begin{array}{l}-0,048 \\
(0,045) \\
\end{array}$ & $\begin{array}{c}\text {-O,IIO* } \\
(0,063)\end{array}$ & $\begin{array}{l}-0,022 \\
(0,016) \\
\end{array}$ \\
\hline Poluga & $\begin{array}{l}-0,364^{* * *} \\
(0,127)\end{array}$ & $\begin{array}{l}-2,968^{* *} \\
(\mathrm{I}, 45 \mathrm{I}) \\
\end{array}$ & $\begin{array}{l}-0,688^{* * *} \\
(0,236) \\
\end{array}$ \\
\hline $\begin{array}{l}\text { Nematerijalna } \\
\text { imovina (t-I) }\end{array}$ & $\begin{array}{l}\text { O,I98 } \\
(0,26 I)\end{array}$ & $\begin{array}{c}2,574^{*} \\
(\mathrm{I}, 708)\end{array}$ & $\begin{array}{l}0,860 \\
(0,73 I)\end{array}$ \\
\hline Strani_20 & $\begin{array}{c}0,027 \\
(0,263)\end{array}$ & $\begin{array}{l}-0,374 \\
(0,348) \\
\end{array}$ & $\begin{array}{l}\text {-O,I59* } \\
(0,09 I)\end{array}$ \\
\hline Osnig9I & $\begin{array}{l}\text { o,6OI*** } \\
(0, \mathrm{I} 27)\end{array}$ & $\begin{array}{c}0,793 \\
(0,562) \\
\end{array}$ & $\begin{array}{c}0,449^{*} \\
(0,259)\end{array}$ \\
\hline R-kvadrat(\%) & 79 & 30 & $7 \mathrm{I}$ \\
\hline $\mathbf{N}$ & 633 & 634 & 403 \\
\hline
\end{tabular}

\section{ZAKLJUČAK}

Utvrđivanje postojanja i definiranje smjera veze između vlasničke strukture i pokazatelja uspješnosti poslovanja jedna je od najvažnijih i najviše raspravljanih tema iz područja korporativnog upravljanja. Međutim, unatoč naporima autora širom svijeta, još uvijek je puno kontradiktornosti i otvorenih pitanja. Ovo, posljednje poglavlje empirijske analize rađene na uzorku tvrtki izlistanih na Zagrebačkoj burzi, predstavlja sažetak dobivenih rezultata.

Postojanje velikog dioničara umanjuje vrijednost Tobinovog Q, dok ne utječe na vrijednost povrata na kapital i učinkovitost rada. Kao objašnjenje ovog rezultata ponuđena je teza kako će moćan i utjecajan vlasnik, u okruženju u kojem zakoni nedovoljno štite male dioničare, pokušati ostvariti vlastite interese nauštrb ostalih vlasnika. Ovakvo ponašanje tjera male investitore $\mathrm{s}$ burze smanjujući tržišnu kapitalizaciju poduzeća, a time i Tobinov Q kao mjeru uspješnosti. Obzirom da postojanje dodatnog dovoljno velikog vlasnika koji je motiviran vršiti nadzor rada najvećeg vlasnika može promijeniti situaciju, ovaj je slučaj posebno ispitan.

Rezultati panel analize pokazuje da postojanje drugog velikog vlasnika ne utječe na uspješnost tvrtke, osim u slučaju kad je taj vlasnik obitelj ili pojedinac. Obitelji imaju snažnu motivaciju za aktivno sudjelovanje u radu poduzeća i sprječavanje zloupotrebe utjecaja prvog velikog vlasnika. Regresijska jednadžba pokazuje veliki, pozitivan i statistički signifikantan utjecaj postojanja obitelji kao drugog velikog vlasnika u poduzeću na vrijednost Tobinovog Q. 
Prihvativši zaključke Guglera i Weiganda (2003) kako veliki vanjski vlasnici utječu na performanse poduzeća egzogeno, dok je menadžersko vlasništvo endogeno, pored panel analize, u slučaju menadžerskog vlasništva primijenjena je i 2 SLS analiza $s$-I vrijednostima kontrolnih varijabli kao instrumentima. Rezultat regresije je granično signifikantan negativan efekt menadžerskog vlasništva na efikasnost rada. Rezultat predstavlja blagu potvrdu hipoteze o „mirnom životu“ menadžera koju su postavili Bertrand i Mullainathana (2003). Onog trenutka kad menadžeri postanu dovoljno utjecajni, s ciljem izbjegavanja sukoba s radnicima i sindikatima, pristaju povećavati plaće i ostale povlastice radnicima umanjujući time efikasnost rada. Povrat na kapital i Tobinov Q nisu pod utjecajem vlasničkog udjela menadžmenta u dioničkoj glavnici.

Unatoč činjenici da je velik broj autora potvrdio pozitivan utjecaj stranog vlasništva na uspješnost poslovanja, posebice u tranzicijskim državama, uzorak hrvatskih tvrtki ne potvrđuje ovo pravilo. U svim regresijskim funkcijama u ovom radu, varijabla za strano vlasništvo ima ili negativan ili statistički nesignifikantan utjecaj na performanse poduzeća. Razlog takvim rezultatima može biti odgođen ulazak stranog kapitala na hrvatsko tržište. Strane investicije postale su obilnije tek nakon 1998, a tada je većina ponajboljih domaćih tvrtki već bila privatizirana od strane domaćih investitora.

Bilo bi interesantno provjeriti rezultate ove empirijske analize na većem i vremenski duljem uzorku koji bi omogućio detaljnije ispitivanje odnosa između dva najveća dioničara, uključujući u model kontrolne varijable za identitet svakog od njih. Međutim, za vrijeme pisanja ovog rada nije bilo moguće doći do detaljnijih i dužih vremenskih nizova podataka što je uvelike ograničilo slobodu autora u definiranju modela. 


\section{LITERATURA}

Anderson, R. and Reeb, D., 2003. Founding-family ownership and firm performance: Evidence from the S\&P 500. Journal of Finance, 58 (3), I3OI-I328. doi: IO.IIII/I540-6261.00567

Barbosa, N. and Louri, H., 2003. "Corporate performance: Does ownership matter? A comparison of foreign and domestic owned firms in Greece and Portugal". Nucleo de Investigacao em Microeconomia Aplicada, Universidade do Minho, WP No. 26.

Becht, M., Bolton, P. and Roell, A., 2002. “Corporate governance and control”. ECGI - Finance Working Paper No. 02/20O2.

Bendekovic, J., 200o. "Privatization in Croatia”. Ekonomski pregled, 5I (I-2) 55-90.

Berle, A. A. and Means, G. C., I932. The Modern Corporation and Private Property. New York: MacMillan Publishing Co.

Bertrand, M. and Mullainathan, S., 2003. "Enjoying the quiet life? Corporate governance and managerial preferences". Journal of Political Economy, III (5), IO43-IO75. doi: IO.IO86/376950

Campbell, J. [et al.], 20oI. "Have individual stocks become more volatile? An empirical exploration of idiosyncratic risk". Journal of Finance, 4I (I), I-44. doi: I0.IIII/O022-I082.003I8

Cho, M., I998. "Ownership structure, investment, and the corporate value: an empirical analysis". Journal of Financial Economics, 47, IO3-I2I. doi: IO.IOI6/So304-4O5X(97)00039-I

Claessens, S., Djankov, S. and Pohl, G., 1997. "Ownership and Corporate Governance-Evidence from the Czech Republic". World Bank Policy Research WP, 1737.

Damijan, J., Gregoric, A. and Prasnikar, J., 2004. “Ownership Concentration and Firm Performance in Slovenia”. LICOS Centre for Transition Economics, Discussion Paper I42/2004.

Demsetz, H. and Lehn, K., 1985. "The structure of ownership: Causes and consequences". Journal of Political Economy, 93 (6), II55-II77. do: IO.IO86/261354

Demsetz, H. and Villalonga, B., 200I. "Ownership structure and corporate performance”. Journal of Corporate Finance, 7 (3), 209-233. doi: Io.IOI6/Sog29-II99(OI)00020-7

Demsetz, H., 1983. "The Structure of Ownership and the Theory of the Firm". Journal of Law and Economics, 26 (82), 375-390. doi: 10.1086/46704I

Farinos, J. E., Garcia, C. and Ibanez, C. J., 2006. "Operating and stock market performance of stateowned enterprise privatizations: The Spanish experience”. SSRN Working Papers series.

Globerman, S., Ries, J. and Vertinsky, I., I994. "The economic performance of foreign affiliates in Canada”.2 Canadian Journal of Economics, 27 (I), I43-I56. doi: 10.2307/I35807

Gregurek, M., 200I. "Level and effects of privatization in Croatia”. Ekonomski pregled, 52 (I-2) I55-I88.

Grosfeld, I. and Tressel, T., 2002. "Competition and ownership structure: substitutes or complements?” Economics of Transition, Io (3), 525-55I. doi: IO.IIII/I468-O35I.toI-I-OOI24

Grosfeld, I., 2006. "Ownership concentration and firm performance: Evidence from an emerging market, Paris-Jourdan Sciences Economiques, Working Paper No. 2006-I8.

Gugler, K. and Weigand, J., 2003. "Is ownership really endogenous?". Applied Economics Letters, Io (8), 483-486. doi: $10.1080 / 1350485032000095357$

Himmelberg, C., Hubbard, G. and Palia, D., 1999. "Understanding the determinants of managerial ownership and the link between ownership and performance". Journal of Financial Economics, 53 (3), 353-384. doi: 10.1016/SO304-405X(99)00025-2

Ivashkovskaya, Z. and Zinkevich, N., 2009. "The relationship between corporate governance and company performance in concentrated ownership systems: The case of Germany". Journal of Corporate Finance, 34-56.

Kapopoulos, L. and Lazaretou, S., 2006. "Corporate ownership structure and firm performance: Evidence from Greek firms”. Bank of Greece Working Paper, No. 37 
Kim, S. K. and Lyn, E., 1990. "FDI theories and the performance of foreign multinationals operating in the United States". Journal of International Business Studies, 2I (I), 4I-54. doi: IO.IO57/palgrave.jibs.8490326

La Porta, R., López de Silanes, F. and Shleifer, A., 1999. "Corporate ownership around the world". Journal of Finance, 54 (2), 47I-5I7. doi: IO.IIII/OO22-I082.00II5

McConnell, J. and Servaes, H., 1990. "Additional evidence on equity ownership and corporate value". Journal of Financial Economics, 27 (2), II9-I49. doi: Io.IOI6/0304-405X(90)90069-C

Miguel, A., Pindado, J. and de la Torre, C., 2004. "Ownership structure and firm value: New evidence from Spain”. Strategic Management Journal, 25 (I2), III9-I2O7.

Morck, R., Shleifer, A. and Vishny, R., 1988. "Management ownership and market valuation”. Journal of Financial Economics, 20 (I-2), 293-315. doi: 10.IOI6/0304-405X(88)90048-7

Shleifer, A. and Vishny, R., 1986. "Large shareholders and corporate control". Journal of PoliticalEconomy, 94 (3), 46I-488. doi: Io.1086/261385

Shleifer, A. and VishnyR., 1997. "A Survey of Corporate Governance”. The Journal of Finance 52 (2), 737783. doi: $10.2307 / 2329497$

Shleifer, A., 1998. "State vs. Private Ownership". Journal of Economic Perspectives, I2 (4), I33-150. doi: IO.I257/jep.I2.4.I33

Thomsen, S. and Pedersen, T., 200o. "Ownership structure and economic performance in the largest European companies”. Strategic Management Journal, 2I (6), 689-705. doi: Io.IO02/(SICI)IO97O266(200006)2I:6<689::AID-SMJII5>3.0.CO;2-Y

Venkatraman, N. and Ramanujam, V., 1986. "Measurement of business performance in strategy research: Comparison of approaches". The Academy of Management Review, II (4), 80I-8I4. 